\title{
COMMENTS
}

\section{Default Judgments in Social Security Claims Litigation}

Default judgments are not favored. ${ }^{1}$ The preferred approach for resolving cases is to have the parties fully and fairly litigate their claims and defenses. ${ }^{2}$ This preference, however, can be overcome by the need to protect a party from extensive delay or disregard of the suit by the opposing party..$^{3}$ The availability of judgment by default encourages parties to defend claims within the time limits provided.

Special problems arise when the United States, its agencies, or its officers are litigants in a civil suit. The government is particularly likely to be slow in its litigation efforts because of its heavy caseload and bureaucratic structure of decisionmaking." These peculiar characteristics make it appropriate for courts to respond differently to delay or default by governmental litigants than to delay by nongovernmental litigants.

Default judgments against the United States are governed by Federal Rule of Civil Procedure 55(e), which permits entry of a default judgment if the government is in default ${ }^{5}$ and the plaintiff

10 C. Wright \& A. Mnler, Frderal Practick and Prockdure § 2681, at 249-51 (1973). See Charlton L. Davis \& Co. v. Fedder Data Center, Inc., 556 F.2d 308, 309 (5th Cir. 1977) ("Judgments by default are a drastic remedy and should be resorted to only in extreme situations.").

- See Gomes v. Williams, 420 F.2d 1364, 1366 (10th Cir. 1970).

s See, e.g., H.F. Livermore Corp. v. Aktiengesellschaft Gebruder Loepfe, 432 F.2d 689, 691 (D.C. Cir. 1970) (citations omitted):

[T] he default judgment must normally be viewed as available only when the adversary process has been halted because of an essentially unresponsive party. In that instance, the diligent party must be protected lest he be faced with interminable delay and continued uncertainty as to his rights. The default judgment remedy serves as such a protection. Furthermore, the possibility of a default is a deterrent to those parties who choose delay as a part of their litigative strategy.

- Giampaoli v. Califano, 628 F.2d 1190, 1194 n.8 (9th Cir. 1980).

- FED. R. Crv. P. 55(a) defines default as a failure to plead or otherwise defend. 
establishes his claim by "evidence satisfactory to the court." Default judgments against the United States under the Social Security Act, ${ }^{7}$ however, appear to require a stricter test. In cases brought by claimants seeking district court review of benefit denials by the Secretary of Health and Human Services, ${ }^{8}$ the courts must look to section $405(\mathrm{~g})$ of Title 42 , which requires that the Secretary's findings of fact be affirmed if supported by "substantial evidence." Section 405(g) makes no provision for claimants to establish their cases directly to the satisfaction of the courts. ${ }^{9}$

The courts are divided over the applicability of section 405(g) in situations of governmental default. Although a majority apply the section strictly, ${ }^{10}$ thereby effectively refusing to punish the Secretary for inexcusable delays, two circuit courts have invoked rule 55(e) or analogous provisions of the Federal Rules in support of a standard of review more favorable to claimants."11

- Id. 55(e) ("No judgment by default shall be entered against the United States or an officer or agency thereof unless the claimant establishes his claim or right to relief by evidence satisfactory to the court.").

T 42 U.S.C. \$\$ 301-1397f (1976).

- The Secretary of Health and Human Services will hereinafter be referred to as the "Secretary." The Department of Health and Human Services ("HHS") inherited the health and welfare responsibilities of the Department of Health, Education and Welfare ("HEW"). See 20 U.S.C. $\$ 3508$ (Supp. IV 1980).

- The text of section 205(g) of the Social Security Act, 42 U.S.C. $\S 405$ (g) (Supp. IV 1980), reads in relevant part:

Any individual, after any final decision of the Secretary made after a hearing to which he was a party, irrespective of the amount in controversy, may obtain a review of such decision by a civil action ... . As part of his answer the Secretary shall file a certified copy of the transcript of the record including the evidence upon which the findings and decision complained of are based. The court shall have power to enter, upon the pleadings and transcript of the record, a judgment affirming, modifying, or reversing the decision of the Secretary, with or without remanding the cause for a rehearing. The findings of the Secretary as to any fact, if supported by substantial evidence, shall be conclusive ... . The court may, on motion of the Secretary made for good cause shown before he files his answer, remand the case to the Secretary for further action by the Secretary, and it may at any time order additional evidence to be taken before the Secretary, but only upon a showing that there is new evidence which is material and that there is good cause for the failure to incorporate such evidence into the record in a prior proceeding; and the Secretary shall, after the case is remanded, and after hearing such additional evidence if so ordered, modify or affirm his findings of fact or its [sic] decision, or both, and shall file with the court any such additional and modified findings of fact and decision, and a transcript of the additional record and testimony upon which his action in modifying or affirming was based. Such additional or modified findings of fact and decision shall be reviewable only to the extent provided for review of the original findings of fact and decision. The judgment of the court shall be final except that it shall be subject to review in the same manner as a judgment in other civil actions.

10 See infra notes 48-56 and accompanying text.

11 See infra notes 57-77 and accompanying text. 
After reviewing the case law and the alternative approaches, this comment concludes that section $405(\mathrm{~g})$ provides the exclusive standard for judicial review and cannot be relaxed merely because the Secretary is in default. The comment then outlines the application of section $405(\mathrm{~g})$ to various situations of governmental default, assesses the mandamus remedy, and concludes with a proposal for legislative reform that would better balance the government's interests and claimants' needs for speedy resolution of benefit disputes.

\section{BACKGROUND}

\section{A. Rule 55(e)}

The entry of a default judgment against a party in federal district court is governed by rule 55. ${ }^{12}$ Proof of a movant's entitlement to relief generally is unnecessary or left to the trial court's discretion. ${ }^{13}$ By relaxing or eliminating the movant's burden of proving the merits of his substantive claim, rule 55 imposes a harsh forfeiture for default.

Rule 55(e), ${ }^{14}$ which governs default judgments against the United States, imposes a more stringent requirement for obtaining a default judgment. Under this rule, a moving party must prove "by evidence satisfactory to the court" his substantive entitlement to relief against the United States. ${ }^{15}$ The federal courts have enter-

12 The entry of default and judgment by default are treated somewhat differently under rule 55 . An entry of default may be entered by the clerk against a party who has "failed to plead or otherwise defend." FroD. R. Crv. P. 55(a). Judgment by default is entered by the clerk only when the plaintiff submits an affidavit of a "sum certain or for a sum which can by computation be made certain" and default has been entered against a defendant who has failed to appear. $I d .55(b)(1)$. If these circumstances do not apply, judgment by default may be entered only by the court, not by the clerk. Id. 55(b)(2). Rule 55(c) provides that an entry of default may be set aside by the court for "good cause." A default judgment may also be set aside under rule $60(\mathrm{~b})$, which provides for relief from a judgment or order. See Alameda v. Secretary of HEW, 622 F.2d 1044, 1048 (1st Cir. 1980) (distinguishing between an "entry of default" against the United States under rule 55(a) for a failure to plead, and a "default judgment[]" under rule 55(e)).

is See generally Annot., 8 A.L.R. FED. 1073, 1087 (1966).

14 See supra note 6. Rule 55(e) is derived from a similar provision in a former section of the Tucker Act, ch. 359, § 6, 24 Stat. 505, 506 (1887) (repealed 1948), which provided that the plaintiff could not prevail against the United States unless he established his claim by "proof satisfactory to the court."

15 To secure a default judgment against the United States a plaintiff must also establish service on the government, see, e.g., Fedor v. Ribicoff, 211 F. Supp. 520, 520 (E.D. Pa. 1962); waiver of sovereign immunity, see, e.g., id.; and subject matter jurisdiction, see, e.g., Carignan v. United States, 48 F.R.D. 323, 325, 328 (D. Mass. 1969), an action by a prisoner against the United States and unnamed agents of the Federal Bureau of Investigation for recovery of personal property. Default was entered after the United States failed to plead. 
tained motions for default judgments against a variety of federal agencies and administrators under this rule. ${ }^{16}$

\section{B. Section $405(\mathrm{~g})$}

Under section $405(\mathrm{~g})$ of Title $42,{ }^{17}$ claimants who are denied Social Security benefits by the Secretary may seek review in federal district court. ${ }^{18}$ This jurisdictional grant vests a district court with "power to enter, upon the pleadings and transcript of the record, a judgment affirming, modifying, or reversing the decision of the Secretary, with or without remanding the cause for a rehearing." 19

After a rule 55(e) hearing, the court denied the government's motion to remove the entry of default but granted its motion to dismiss for want of subject matter jurisdiction, noting that jurisdiction is a prerequisite to any judicial action other than dismissal of a complaint. See also Burton v. Peartree, 326 F. Supp. 755, 759-61 (E.D. Pa. 1971).

The stricter standard of rule 55(e) "arose from recognition that the government was sometimes slow to respond to a complaint and that the public fisc should be protected against payment of unfounded claims solely because of a failure to respond timely." Giampaoli v. Califano, 628 F.2d 1190, 1193-94 (9th Cir. 1980) (footnote and citation omitted). See also Klapprott v. United States, 335 U.S. 601, 611 (1949) (dictum) ("Rule 55(e) expressly bars all judgments against the United States without proof . . . ."); United States v. Roundtree, 420 F.2d 845, 853-54 (5th Cir. 1969); United States v. Geisler, 174 F.2d 992, 999 (7th Cir.), cert. denied, 338 U.S. 861 (1949); Turner v. Department of Army, 447 F. Supp. 1207, 1213 n.22 (D.D.C. 1978), aff'd mem., 593 F.2d 1372 (D.C. Cir. 1979).

${ }_{16}$ E.g., Mason v. Lister, 562 F.2d 343, 345 (5th Cir. 1977) (applying rule in federal employee's suit challenging validity of Federal Employees Early Retirement Act); United States v. Roundtree, 420 F.2d 845, 853 (5th Cir. 1969) (applying rule in IRS action against taxpayer when IRS failed timely to answer counterclaim); United States v. Geisler, 174 F.2d 992, 999 (7th Cir.) (applying rule in denaturalization proceedings), cert. denied, 338 U.S. 861 (1949); Turner v. Department of Army, 447 F. Supp. 1207, 1213 n.22 (D.D.C. 1978) (applying rule in action by former Army chaplain asking court to revise his military service record), aff'd mem., 593 F.2d 1372 (D.C. Cir. 1979); see also Knouff v. United States, 74 F.R.D. 555, 556-57 (W.D. Pa. 1977); United States v. Zulli, 418 F. Supp. 252, 253 (E.D. Pa. 1975); Greenbaum v. United States, 360 F. Supp. 784, 789 (E.D. Pa. 1973); Burton v. Peartree, 326 F. Supp. 755, 759 (E.D. Pa. 1971).

17 See supra note 9.

18 Judicial review directly affects only about one beneficiary in 3,000; only one beneficiary out of 9,000 is granted benefits as a result of judicial review. E. YourMAN, REPORT ON A Study of Social Security Hearings, Appeals, and Judicial Review, reprinted in Subcomm. on Social Security of the Comm. on Ways and Means, 94th Cong., 1st Sess., Recent Studies Relevant to the Disabitity Hearings and Appeals Crisis 125, 160-61 (Comm. Print 1975). About 8,000 to 10,000 new cases are filed in federal district court each year regarding disability benefits alone. Hearings on H.R. 3236 and 3464 Before the Senate Comm. on Finance, 96th Cong., 1st Sess. 82 (1979) (statement of Commissioner of Social Security Stanford G. Ross).

1242 U.S.C. $\$ 405$ (g) (Supp. IV 1980). See supra note 9. If new evidence is submitted to the court, the appropriate disposition will usually be to remand to the Secretary for a further hearing. See, e.g., King v. Califano, 599 F.2d 597, 599 (4th Cir. 1979) (remand is appropriate "when new evidence is submitted to a reviewing court if the court concludes that the Secretary's decision might reasonably have been different had that evidence been before 
Section 405(g) also provides the standard for reviewing denials of benefit claims: the Secretary's findings "as to any fact, if supported by substantial evidence, shall be conclusive."20 Substantial evidence has been defined as " such relevant evidence as a reasonable mind might accept as adequate to support a conclusion.' "21 Findings of fact include inferences supported by substantial evidence; ${ }^{22}$ the court on review must consider the record as a whole, including the pleadings and a transcript of the administrative record. ${ }^{23}$ Although the reviewing court may believe that the evidence supports the claimant, it must uphold the Secretary if substantial evidence supports his factual findings. ${ }^{24}$

Section $405(\mathrm{~h})^{25}$ makes the jurisdictional and evidentiary provisions of section $405(\mathrm{~g})$ exclusive. Under section $405(\mathrm{~h})$, jurisdiction over factual issues in claims denials may not be grounded on general federal question jurisdiction ${ }^{26}$ or on the jurisdictional pro-

him when his decision was rendered").

2042 U.S.C. $\$ 405(\mathrm{~g})$ (Supp. IV 1980).

${ }^{21}$ Richardson v. Perales, 402 U.S. 389, 401 (1971) (quoting Consolidated Edison Co. v. NLRB, 305 U.S. 197, 229 (1938)).

${ }^{22}$ Cody v. Ribicoff, 289 F.2d 394, 395 (8th Cir. 1961); Carqueville v. Flemming, 263 F.2d 875, 877 (7th Cir. 1959); Folsom v. O'Neal, 250 F.2d 946, 947 (10th Cir. 1957).

${ }^{23}$ Hephner v. Mathews, 574 F.2d 359, 362 (6th Cir. 1978) ("We may not focus and base our decision entirely on a single piece of evidence, and disregard other pertinent evidence."); Russell v. Secretary of HEW, 540 F.2d 353, 357 (8th Cir. 1976) ("This court is not free to overturn the Secretary's decision on the basis of weight and credibility of evidence where the decision has been based on the record as a whole.").

24 Estep v. Richardson, 459 F.2d 1015, 1016-17 (4th Cir. 1972) (section 405(g) "precludes a reviewing court from deciding a claim on its own independent findings"). Accord, Laffoon v. Califano, 558 F.2d 253, 254 (5th Cir. 1977); Lightcap v. Celebrezze, 214 F. Supp. 209, 213 (W.D. Pa. 1962). See also Russell v. Secretary of HEW, 540 F.2d 353, 356 (8th Cir. 1976).

${ }^{23} 42$ U.S.C.A. $\$ 405(\mathrm{~h})$ (West Supp. 1982) provides in full:

The findings and decisions of the Secretary after a hearing shall be binding upon all individuals who were parties to such hearing. No findings of fact or decision of the Secretary shall be reviewed by any person, tribunal, or governmental agency except as herein provided. No action against the United States, the Secretary, or any officer or employee thereof shall be brought under section 1331 or 1346 of Title 28 to recover on any claim arising under this subchapter.

${ }^{28} 28$ U.S.C. § 1331 (Supp. IV 1980). See Weinberger v. Salfi, 422 U.S. 749 (1975), a class action brought to challenge a Social Security requirement that the claimant must have been married to the wage earner nine months before his death to receive insurance benefits. The district court had read the last sentence of section 405(h) as "no more than a codification of the doctrine of exhaustion of administrative remedies," and found jurisdiction under section 1331. Id. at 757. The Supreme Court held that section $405(\mathrm{~h})$ requires more, as "is plain from its own language, which is sweeping and direct and which states plainly that no action shall be brought under $\S 1331$." Id. (emphasis in original). The Court held that section 405 provides both standing and the substantive test on review. Id. at 760-61. One dissent, arguing that there was jurisdiction under section 1331 because the complaint included constitutional issues, stated that "[s]ection $405(\mathrm{~h}) \ldots$ only bans, except under $\S 405(\mathrm{~g})$, 
vision of the Federal Tort Claims Act. ${ }^{27}$ In Califano $v$. Sanders, ${ }^{28}$ the Supreme Court held that section 405(h) also precludes jurisdiction under the Administrative Procedure Act.29 Section 405(h) provides further that "[n]o findings of fact or decision of the Secretary shall be reviewed by any person, tribunal, or governmental agency except as herein provided."so The standard of review is located in section $405(\mathrm{~g})$ : the substantial evidence standard. ${ }^{31}$

\section{Delay in Claims Litigation}

Although a claimant whose bid for Social Security benefits is denied by the Secretary may recoup delayed benefit payments if he successfully appeals the denial, ${ }^{32}$ this process is lengthy and may inflict substantial hardship. The Secretary has frequently been castigated by the courts for delay and inaction in Social Security suits;"3 the claims process has been cited as a "labyrinth,"3s a "maze,"ss and "uncomfortably reminiscent of Alice's trip through Wonderland."

suits which . . require the application of the statute to a set of facts, and which seek nothing more than a determination of eligibility claimed to arise under the Act." Id. at 789 (Brennan, J., dissenting).

${ }^{27} 28$ U.S.C. $\$ 1346$ (1976).

28430 U.S. 99,107 (1977).

35 U.S.C. $\$ \S 701-706$ (1976).

so 42 U.S.C.A. § 405(h) (West Supp. 1982). See supra note 25.

${ }^{31}$ Sections $405(\mathrm{~g})$ and (h) apply only to the Secretary's findings of fact. Thus, when a claimant's appeal involves a constitutional challenge, rule 55(e) may apply. Thomas v. Harris, 30 Fed. R. Serv. 2d 1628, 1629-30 (E.D. Mo. 1980).

32 Nonpayment during the delay caused by the review process would be an "underpayment," 20 C.F.R. $\S 404.501$ (1981), and the Secretary would pay the balance due to the claimant, or, if the claimant were deceased, to his surviving spouse or children. 42 U.S.C. $\$$ 404(a)(2) (1976). Payments would be made from the date of filing the application or from the first month all requirements for entitlement were met, up to 12 months before the application, whichever was earlier. 20 C.F.R. $\$ \S 404.501,404.621$ (1981). See Jimenez v. Weinberger, 523 F.2d 689, 704 (7th Cir. 1975) ("Congress intended that Social Security beneficiaries receive the full and correct amount of their entitlement, even if this requires payments to be made long after the period of entitlement.") (footnote omitted).

ss See, e.g., Giampaoli v. Califano, 628 F.2d 1190, 1195 \& n.12 (9th Cir. 1980) ("poor and disabled persons . . . suffer because of the 'glacial pace' at which HEW conducts its administrative disability proceedings") (citation omitted); Carroll v. Secretary of HEW, 470 F.2d 252, 253 (5th Cir. 1972); Santiago v. Secretary of HEW, 82 F.R.D. 164, 166 (D.P.R. 1979) (condemning the "Secretary's systematic record of flagrant disobedience to judicial authority and obstinate abuse of this court's leniency"), vacated and remanded sub nom. Alameda v. Secretary of HEW, 622 F.2d 1044 (1st Cir. 1980).

s4 Giampaoli v. Califano, 628 F.2d 1190, 1191 (9th Cir. 1980).

ss Carroll v. Secretary of HEW, 470 F.2d 252, 253 (5th Cir. 1972).

s* Id. See also Giampaoli v. Califano, 628 F.2d 1190, 1195 n.12 (9th Cir. 1980) ("HEW has been almost singly responsible for the development of the jurisprudence of rule $55(e) . ")$. 
In addition to the "glacial pace"s7 common in all governmental litigation, ${ }^{38}$ the benefit appeals process is particularly drawn out because of section 405 (g)'s requirement that the Secretary file with his answer a certified copy of the transcript of the administrative record..$^{3 \theta}$ The record is not transcribed until judicial review is sought by a claimant, and transcription, which requires playing a tape and identifying voices, is an "inherently slow" process. ${ }^{10}$ After transcription, the record is reviewed by the Department of Health and Human Services to decide whether to resist the claimant. If the decision is affirmative, the Department of Justice is then instructed to file an answer for the Secretary. ${ }^{11}$ Although the answer must be filed within sixty days of a claimant's complaint, ${ }^{42}$ the process of transcription and review frequently results in the Secretary's default.

\section{ANAL YSIS}

The Secretary may default in several ways: he may file nothing; ${ }^{13}$ he may file a motion to postpone; ${ }^{44}$ or he may file an answer and transcript without a brief or supporting memorandum of law.45 Section 405(g) commands the Secretary to file a copy of the record as part of his answer ${ }^{46}$ and requires the reviewing court to base its decision on review of the record. ${ }^{47}$ A problem arises, however, when section $405(\mathrm{~g})$ 's requirement of substantial evidence in the record

37 Giampaoli v. Califano, 628 F.2d 1190, 1195 \& n.12 (9th Cir. 1980).

so Id. at 1194 n.8.

39 42 U.S.C. $\$ 405(\mathrm{~g})$ (Supp. IV 1980). See supra note 9.

10 Villines v. Harris, 487 F. Supp. 1278, 1281-82 (D.N.J. 1980).

41 Id.

43 The Act contains no express time limit for filing. It simply requires the Secretary to file a certified copy of the transcript of the record "[a]s part of his answer." 42 U.S.C. $\S 405$ (g) (Supp. IV 1980). However, FED. R. Crv. P. 12(a) provides that "[t]he United States or an officer or agency thereof shall serve an answer to the complaint ... . within 60 days after the service upon the United States attorney of the pleading in which the claim is asserted." See also Villines v. Harris, 487 F. Supp. 1278, 1280 (D.N.J. 1980).

${ }^{13}$ Cf. Rank v. Krug, 142 F. Supp. 1, 87-89 (S.D. Cal. 1956) (United States did not appear or file a responsive pleading), modified sub nom. California v. Rank, 293 F.2d 340 (9th Cir. 1961), aff'd sub nom. Dugan v. Rank, 372 U.S. 609 (1963). This has apparently never happened in a Social Security case.

"See, e.g., Williams v. Califano, 593 F.2d 282, 283-84 (7th Cir. 1979); Howard v. Weinberger, 489 F.2d 216, 217 (5th Cir. 1974).

43 See, e.g., Alameda v. Secretary of HEW, 622 F.2d 1044, 1045 (1st Cir. 1980). Cf. Bostic v. Harris, 484 F. Supp. 686, 688 (S.D.W. Va. 1979) (filing of transcript out of time allowed; filing of answer precluded).

(8 42 U.S.C. $\$ 405$ (g) (Supp. IV 1980) ("As part of his answer the Secretary shall file a certified copy of the transcript of the record . . . .").

${ }^{4}$ Id. See supra note 9. 
combines with failure by the Secretary to produce a copy of the record.

A district court confronted with a default by the Secretary might respond in one of three ways. Invoking rule 55(e), it might enter a default judgment against the government if the claimant proves his claim "by evidence satisfactory to the court." Alternatively, it might invoke section $405(\mathrm{~g})$, holding that the substantial evidence test requires it to await the Secretary's response and then to review the record for substantial evidence supporting his position. Finally, a court might invoke other sanctions against the Secretary for his default. After reviewing the case law, this part considers these alternatives in turn, concluding that review under section $405(\mathrm{~g})$ is the only permissible route. The part then outlines a way for the courts to respond to the Secretary when he is in default that is consistent with section $405(\mathrm{~g})$.

\section{A. The Case Law}

A majority of courts, including the Fifth, ${ }^{48}$ Sixth, ${ }^{48}$ and Seventh ${ }^{\mathrm{BO}}$ Circuits, have held that the substantial evidence standard of section 405(g) must be applied on review despite default by the Secretary, even in cases in which he fails to file an answer or submit the transcript of the administrative record with his pleading..$^{51}$ Acknowledging the general applicability of rule 55(e) in cases of default by the United States, these courts incorporate the section $405(\mathrm{~g})$ requirement into rule 55(e)'s "evidence satisfactory to the

48 See, e.g., Howard v. Weinberger, 489 F.2d 216, 217 (5th Cir. 1974) (default judgment reversed; section $405(\mathrm{~g})$ applies); Carroll v. Secretary of HEW, 470 F.2d 252, 256 (5th Cir. 1972) (default judgment vacated; evidence "satisfactory to the court" must include evidence sufficient to "conduct review in accordance with 42 U.S.C. $\S 405(\mathrm{~g})$ ").

49 See, e.g., Poe v. Mathews, 572 F.2d 137, 138 (6th Cir. 1978) (per curiam) (default judgment reversed; a "claim or right to relief" under rule 55(e) requires review of the record under section $405(\mathrm{~g})$ ).

so See, e.g., Williams v. Califano, 593 F.2d 282, 284-85 (7th Cir. 1979) (default judgment vacated; "right to relief by evidence satisfactory to the court" can be established only by a showing in accordance with section $405(\mathrm{~g})$ that the Secretary's decision is not "supported by substantial evidence").

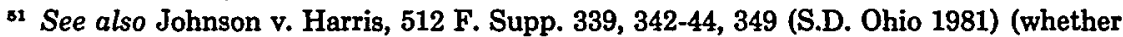
styled summary or default judgment, plaintiff entitled to judgment if under section $405(\mathrm{~g})$ the Secretary's decision is not supported by substantial evidence); Villines v. Harris, $487 \mathrm{~F}$. Supp. 1278, 1281 (D.N.J. 1980) (court may not ignore the statutory command that the transcript of the administrative hearing be filed "as part of the answer," and therefore had "no course but to allow the answer, including the transcript which is part of it, to be filed" late); Bostic v. Harris, 484 F. Supp. 686, 687, 692-93 (S.D.W. Va. 1979) (default judgment granted after review of the record; in cases involving rule 55(e) and section $405(\mathrm{~g})$ the standard of evidence "is that of the statute"). 
court" standard.

Williams v. Califano ${ }^{52}$ is typical. In that case, the Secretary's answer was not timely filed because of delay in preparing the administrative record. The district judge denied a request for an extension of time, finding that the delay was due to inexcusable neglect. By the time of the hearing on the plaintiff's default judgment motion, the Secretary had submitted a transcript. The district court, however, did not consider itself bound by the administrative record; it found evidence sufficient to support the plaintiff's claim and entered default judgment under rule $55(\mathrm{e}) .^{53}$

The Seventh Circuit vacated the judgment, pointing to two errors. ${ }^{\text {s4 }}$ First, the district judge had conducted a de novo review, had not given any weight to the determination of the administrative law judge, and had not confined himself to the evidence presented at the administrative hearing. Second, the district judge had looked for evidence sufficient to support the plaintiff's claim rather than for evidence sufficient to support the Secretary. The Seventh Circuit held that, in "considering the interaction of $\S 405(\mathrm{~g})$ and Rule 55(e)," default judgment cannot be entered without consideration of the record. ${ }^{\mathrm{s}}$ If the reviewing court determines that there is substantial evidence in the record supporting the Secretary, it must hold in his favor. ${ }^{.6}$

Two circuits have departed from this approach. In Alameda $v$. Secretary of $H E W, 57$ the First Circuit vacated a default judgment entered by the district court ${ }^{88}$ when the Secretary failed to file a brief. In remanding, the First Circuit stated that "so long as $\S 405$ (g) has any force, claimant can 'establish his claim' only by showing that there is no 'substantial evidence' supporting the Secretary." After balancing several "legitimate interests," the First Circuit held that when the Secretary fails to file a brief, the reviewing court need not "comb the record for substantial evi-

s2 593 F.2d 282 (7th Cir. 1979).

ss Id. at 284.

st Id. at 284-85.

Id.

so. $I d$.

s7 622 F.2d 1044, 1048 (1st Cir. 1980).

s Santiago v. Secretary of HEW, 463 F. Supp. 759, 760 (D.P.R.), motion to vacate denied, 82 F.R.D. 164 (D.P.R. 1979).

so 622 F.2d at 1048 (citation omitted).

* Id. at 1047. The court considered the need to process Social Security claims quickly, the plaintiff's statutory burden of proof, the court's interest in the functioning of the adversary system, and the taxpayers' interest in avoiding windfalls to individual litigants. Id. at $1047,1049$. 
dence with which to uphold the administrative decision." Instead, it can undertake the more "relaxed review contemplated by Rule 55(e)," relying on the claimant's brief to identify a lack of sufficient evidence in the record to support the Secretary's conclusion. ${ }^{82}$ When the Secretary fails to file a brief, "the quantum and quality of evidence that might satisfy a court can be less than [that] normally required" under section $405(\mathrm{~g}) .^{63}$ Strict adherence to section $405(\mathrm{~g})$, the court emphasized, would undermine the "meaning" and "purpose" of rule 55(e). ${ }^{\text {.4 }}$

The Ninth Circuit rejected the section 405(g) substantial evidence standard in Giampaoli $v$. Califano. ${ }^{65}$ In that case, the district court found the claimant had met her burden of proving that she was unable to perform her former jobs but held the Secretary had not met his burden of demonstrating that she could perform other jobs. ${ }^{6 B}$ The district court remanded for further administrative proceedings; when none was forthcoming, the court entered judgment for the claimant. ${ }^{67}$

The Ninth Circuit affirmed in an opinion that did not invoke section $405(\mathrm{~g}) .^{.8}$ The court relaxed the evidentiary standard even further by restricting the scope of rule 55(e). It styled its decision as a judgment on the merits-not as a default judgment ${ }^{68}$-and held that "rule 55(e) [and its "evidence satisfactory to the court" standard] does not apply once the plaintiff has presented a prima facie case and thereby shifted the burden of proof to the government."70 The court construed rule 55(e) narrowly, holding that it

\footnotetext{
61 Id. at 1047.

22 Id. at 1048-49.

is Id. at 1048.

os Id.

os 628 F.2d 1190 (9th Cir. 1980).
}

Be Id. at 1192. The burden of proof in a disability hearing is bifurcated. See Annot., 22 A.L.R.3d 440, 445 (1968), describing the burden of proof as requiring the claimant to show a medically determinable physical disability which prevents him from engaging in his past occupation [and] evidence that he has no training or experience for any other type of work. The burden is then generally held to shift to the Secretary to show that the claimant can engage in some substantial gainful employment, and the availability of any such employment.

o7 628 F.2d at 1193.

os Id. at 1196.

$I$ Id.

70 Id. at 1195-96. The court distinguished this case from Carroll v. Secretary of HEW, 470 F.2d 252 (5th Cir. 1972). In Carroll, the district court remanded to the Secretary for further factual findings as to the claimant's date of birth. When the Secretary failed to file the supplemental transcript on time, the court entered a default judgment for the claimant. Id. at 254. The Fifth Circuit held that the remand to the Secretary indicated that the district court was not satisfied that there was enough evidence in the record supporting the 
applies only to cases in which the government fails to respond to a complaint. $^{.1}$

Both the First Circuit in Alameda ${ }^{72}$ and the Ninth Circuit in

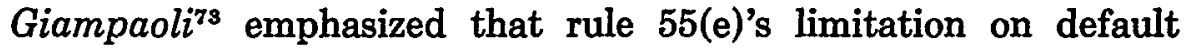
judgments does not relieve the government of its duty to obey court orders. They justified this emphasis by analogizing to cases in which sanctions having the effect of a default judgment are imposed under Federal Rule of Civil Procedure $37(b)(2)^{74}$ for failure to comply with discovery orders. ${ }^{75}$ The imposition of rule 37 sanc-

claimant, and that judgment for the claimant was therefore precluded. Id. at 256. In Giampaoli, the court accepted the Fifth Circuit's characterization of Carroll and distinguished the case at hand on the ground that the plaintiff "has done all that she was required to do." 628 F.2d at 1195 n.11.

${ }^{71} I d$. at 1193-94. According to the court, a narrow construction of rule 55(e) is preferable because the rule "puts the government in a privileged position above all other litigants. If this privilege is interpreted too broadly, the government obtains an undue advantage, which enhances its strategic position and upsets the overriding policy that civil litigants receive equal treatment." Id. at 1195 . Limiting the protection of rule $55(\mathrm{e})$ to cases involving the government's failure to respond to a claimant, however, is unnecessarily extreme. Default judgments are entered against the government for reasons other than failure to answer a complaint; for example, one of the sanctions available for failure to comply with discovery orders is a judgment by default. See FED. R. Civ. P. 37(b)(2)(C); infra note 74. The language of rule 55(e) would appear to apply to such cases, regardless of whether the government has answered the complaint.

${ }^{72} 622$ F.2d 1044, 1048 \& n.4 (1st Cir. 1980).

73628 F.2d 1190, 1194 (9th Cir. 1980).

74 FED. R. CIv. P. 37(b)(2) provides that where a party

fails to obey an order to provide or permit discovery . . . the court in which the action is pending may make such orders in regard to the failure as are just, and among others the following:

(A) An order that the matters regarding which the order was made or any other designated facts shall be taken to be established for purposes of the action in accordance with the claim of the party obtaining the order;

(B) An order refusing to allow the disobedient party to support or oppose designated claims or defenses, or prohibiting him from introducing designated matters in evidence;

(C) An order striking out pleadings or parts thereof, or staying further proceedings until the order is obeyed, or dismissing the action or proceeding or any part thereof, or rendering a judgment by default against the disobedient party.

${ }^{75}$ On the use of the rule $37(\mathrm{~b})(2)$ sanction against the government, see $6 \mathrm{~J}$. Moors, Federal Practice I 55.12 (2d ed. 1972); 10 C. Wright \& A. Miller, supra note 1, § 2702; Developments in the Law-Discovery, 74 Harv. L. Rev. 940, 988-89 (1961). In Socialist Workers Party v. Attorney General, 596 F.2d 58 (2d Cir.), cert. denied, 444 U.S. 903 (1979), the Second Circuit vacated a contempt order issued against the United States Attorney General for failure to release files to the plaintiffs, but remanded for the district court to consider the imposition of issue-related sanctions, which would put the plaintiffs in the same position they would have been in if the files had been disclosed. Id. at 65-67. The court stated that a partial default judgment, such as one on particular issues of fact, can be entered against the United States despite the provisions of rule 55(e). Id. at 66 n.15. See also United States v. Sumitomo Marine \& Fire Ins. Co., 617 F.2d 1365, 1370 (9th Cir. 1980) (rule 55(e) does not immunize government from rule $37(\mathrm{~b})$ order precluding government from 
tions, such as an order establishing facts in accordance with the claim of the party obtaining the order, ${ }^{78}$ does not require a rule 55(e) showing, even though the effect is similar to a default judgment. ${ }^{77}$

The circuits are therefore in sharp disagreement over the application of section $405(\mathrm{~g})$ 's substantial evidence requirement to situations of governmental default. Under the majority approach, the courts must always review the record for substantial evidence in favor of the Secretary, even where he is in default; accordingly, resolution must be delayed until he produces the record. Under the First Circuit's test, the courts can apply a "relaxed review" when the Secretary is in default. Under the Ninth Circuit's approach, the courts can simply accept a claimant's assertions as fact and enter a judgment on the merits, at least where he has made out a prima facie case.

\section{B. Rule 55(e) vs. Section 405(g)}

It might be argued that Congress did not consider the problem of default judgments when it enacted section $405(\mathrm{~g})$ and that the rule 55(e) standard should therefore be incorporated into the So-

presenting evidence on issue of damages; sanction imposed for failure to comply with discovery order); Reynolds v. United States, 192 F.2d 987, 998 (3d Cir. 1951) (facts can be taken as established against the government when it refuses to produce documents), rev'd on other grounds, 345 U.S. 1 (1953); Perry v. Golub, 74 F.R.D. 360, 368 (N.D. Ala. 1976) (dismissal of defendant's petition due to willful failure to respond within proper time to the plaintiff's request for production of documents was not a default judgment requiring a rule 55(e) showing), petition denied sub nom. Falkowski v. Perry, 464 F. Supp. 1016 (N.D. Ala. 1978); Kahn v. Secretary of HEW, 53 F.R.D. 241, 245-46 (D. Mass. 1971) (order deeming facts to be taken as established required no rule 55(e) showing); International Ass'n of Machinists v. National Mediation Bd., 314 F. Supp. 229, 232 (D.D.C. 1969) (order striking Board's evasive answers to interrogatories and granting summary judgment to the plaintiff not subject to rule 55(e)); Jackson Buff Corp. v. Marcelle, 20 F.R.D. 139, 140 (E.D.N.Y. 1957) (dictum) (government bound to answer requests for admission like any other litigant; sanctions other than default can be imposed without a rule 55(e) showing). Cf. O'Neill v. United States, 79 F. Supp. 827, 830-31 (E.D. Pa. 1948) (although rule 55(e) does not apply in admiralty, court adopted policies behind the rule and declined to enter default judgment, imposing discovery sanctions instead), rev'd on other grounds sub nom. Alltmont v. United States, 174 F.2d 931 (3d Cir. 1949) (per curiam).

${ }^{78}$ See FED. R. Civ. P. 37(b)(2)(A); see also Reynolds v. United States, 192 F.2d 987, 990 (3d Cir. 1951) (ordering that facts in plaintiffs' favor on issue of negligence be taken as established after government failed to produce documents for court inspection), rev'd on other grounds, 345 U.S. 1 (1953). Sanctions can also include a prohibition on the use of certain claims or defenses, FED. R. Crv. P. 37(b)(2)(B); or an order striking pleadings, dismissing the action, or rendering default judgment, id. $37(\mathrm{~b})(2)(\mathrm{C})$.

${ }^{27}$ When a rule 37 order does take the form of a default judgment under rule 37(b)(2)(C), however, it must satisfy the requirements of rule 55 as well. See United States v. Sumitomo Marine \& Fire Ins. Co., 617 F.2d 1365, 1370 (9th Cir. 1980). 
cial Security Act. Although section 405(g) deals with claims appeals in general, rule 55(e) specifically addresses the problem of governmental default; it is a maxim of statutory construction that specific statutes take precedence over general statutory provisions. ${ }^{78}$ The courts have read provisions of the Federal Rules of Civil Procedure into the Social Security Act in other contexts. For example, the Act is silent on the procedural time limit within which the Secretary must file an answer; the courts have incorporated the sixty-day time limit of rule $12(a) .^{79}$

This argument is flawed for several reasons. The general/specific rule of construction is of little use here, for it can be argued that rule 55(e) is in fact the general provision, providing the usual evidentiary standard, while section 405 (g) embodies the specific, "substantial evidence" exception to that standard. Moreover, the rule 12(a) analogy is inapposite: the Social Security Act contains no time provision, but it does contain a provision governing evidentiary review of the record. In addition, section 405(h) makes the substantial evidence standard exclusive, ${ }^{80}$ and a rule permitting a claimant to prove his claim by presenting evidence satisfactory to the court directly conflicts with this command. In the Social Security context the district court does not act in its usual factfinding role, but sits as an appellate tribunal to review the record before it.

If rule 55(e) applied in terms, the court could review for evidence satisfactory to it if the Secretary defaulted through failure to file a brief, even if the administrative record were available. ${ }^{81}$ Such a rule seems to be in direct conflict with section $405(\mathrm{~g})$, requiring review of the record. Where the Secretary failed to file a transcript of the record, the rule 55(e) argument is stronger. Rather than continuing to grant the Secretary's motions to extend, the court, unable to evaluate the record, might grant a default judgment based on evidence presented by the claimant.

Such an application of rule 55(e), however, still appears to conflict with section $405(\mathrm{~h})$, which limits review to the standard

38 See 1A C. Sands, Sutherdand's Statutes and Statutory Construction $\$ 23.16$, at 248 (4th ed. 1972) ("A general statute applies to all persons and localities within its jurisdictional scope, prescribing the governing law upon the subject it encompasses, unless a special statute exists to treat a refinement of the subject with particularity or to prescribe a different law for a particular locality.") (footnote omitted).

70 See supra note 42 and accompanying text.

so See supra note 25 and accompanying text.

s1 See Alameda v. Secretary of HEW, 622 F.2d 1044 (1st Cir. 1980). 
defined in section $405(\mathrm{~g}) .^{82}$ Section $405(\mathrm{~g})$ requires an evaluation of the evidence in the administrative record that supports the decision of the Secretary. The claimant's burden is to show that the evidence is not substantial, and he cannot attempt this showing without the record. Moreover, even if the claimant could reproduce for the reviewing court the evidence presented at the administrative hearing, the court could not, consistent with section $405(\mathrm{~g})$, rely on his showing without considering the evidence supporting the Secretary. ${ }^{83}$

Judicial efforts to circumvent the strict requirements of section $405(\mathrm{~g})$ carry decided equitable overtones, ${ }^{84}$ and the unfairness to claimants facing recurrent delays is manifest. Because the claims situation involves the public fisc, however, the courts must apply section $405(\mathrm{~g})$ strictly: the Supreme Court has long emphasized the duty of courts to observe scrupulously the conditions defined by Congress for granting governmental benefits. ${ }^{8 \mathrm{~s}}$ Relaxation of the substantial evidence standard would impermissibly intrude on Congress's control over benefit payments. The only way to mesh rule $55(\mathrm{e})$ and section $405(\mathrm{~g})$ is to incorporate the substantial evidence showing as the required "evidence satisfactory to the court" under rule 55(e).

\section{Rule 37}

The First ${ }^{88}$ and Ninth ${ }^{87}$ Circuits have pointed to cases imposing sanctions against the government under rule 37 for failure to

${ }^{82}$ See Williams v. Califano, 593 F.2d 282, $284 \&$ n.2 (7th Cir. 1979) (construing Weinberger v. Salf, 422 U.S. 749 (1975)); Villines v. Harris, 487 F. Supp. 1278, 1281 (D.N.J. 1980).

${ }^{83}$ Compare Alameda v. Secretary of HEW, 622 F.2d 1044, 1049 (1st Cir. 1980), a case in which the transcript was filed but the government failed to submit a required memorandum. Permitting a "relaxed review" under rule 55, $i d$. at 1048-49, the court stated:

We would not easily set aside the judgment if the entry of default was justified and the claimant's district court brief and reference to the [administrative] record appeared relevant, fair and reasonably comprehensive. If the brief should entirely lack these virtues or refer to evidence supporting the Secretary's decision that was clearly "substantial," we would have no choice but to reverse.

Id. at 1049.

s4 Compare Giampaoli v. Califano, 628 F.2d 1190, 1194-95 (9th Cir. 1980); Alameda v. Secretary of HEW, 622 F.2d 1044, 1047 (1st Cir. 1980), both balancing "policies" and "interests" implicated by the default issue.

ss See Schweiker v. Hansen, 450 U.S. 785, 788 (1981); Federal Crop Ins. Corp. v. Merrill, 332 U.S. 380, 384 (1947); Goldberg v. Weinberger, 546 F.2d 477, 480-81 (2d Cir. 1976); American Training Serv., Inc. v. Veterans Admin., 434 F. Supp. 988, 1001 (D.N.J. 1977).

so See supra note 72 and accompanying text.

37 See supra note 73 and accompanying text. 
produce in response to discovery requests. Such sanctions can include an order that designated facts be taken as established in accordance with the claim of the party seeking discovery; ${ }^{88}$ such an order can have the effect, though not the form, of a default judgment. In the Social Security context, a court that took as established a claimant's factual contentions would arguably avoid the problems of rule 55(e) and section $405(\mathrm{~g})$; once a fact is accepted, the burden-of-proof issue is moot.

The discovery sanction analogy is not appropriate in the Social Security context, however. First, a rule 37 sanction in a Social Security case so clearly has the effect of a default judgment that it should be limited to its context-violations of discovery orders. ${ }^{89}$ The Secretary's duty to file a transcript of the administrative record is a pleading requirement and not a matter of discovery.90 Moreover, adopting the rule 37 analogy would violate the language of section $405(\mathrm{~g})$. Rule 37 permits a court to take as established a claimant's designated facts, but section 405 (g) requires an examination of the evidence in the administrative record.

\section{Applying Section 405(g)}

Once the rule 55(e) and rule 37 options are rejected, a court is arguably at the mercy of the Secretary. If section $405(\mathrm{~g})$ requires review based on the administrative record, the court cannot act until the record is produced. Such an outcome can be criticized as unjust, unworkable, and as placing the Secretary instead of the courts in effective control of claims litigation. ${ }^{21}$ There are two responses to this argument: first, that it is a matter for congressional, not judicial, resolution; ${ }^{22}$ and second, that it does not preclude the courts from following a course of action that is manageable and consistent with the Social Security Act. This section outlines such a course of action.

1. Administrative record unavailable and Secretary does not intend to defend. If the Secretary altogether fails to respond to a claimant's complaint, he may be deemed to concede the case. This situation apparently presents only a conceptual problem. In prac-

see supra note 76 and accompanying text.

"One might question the legitimacy, even in the discovery sanction cases, of a court entering an order that has the effect of a default judgment so as to avoid an established test for entry of a default judgment.

042 U.S.C. § 405(g) (Supp. IV 1980); see supra note 9.

-1 See supra notes 43-47 and accompanying text.

"See infra part III. 
tice, the Secretary will request a remand for an additional hearing if he does not have enough evidence to evaluate the claim, ${ }^{93}$ or file for an extension of time if the transcript has not been produced.94 Such actions indicate that the Secretary has not yet decided whether to contest the claimant's appeal. Once the decision not to contest the claim has been made, the Secretary should, before he files an answer, request a remand for computation of benefits. ${ }^{98}$ Such a motion approximates a confession of error and relieves the court of the need to decide the case on the merits in accordance with section $405(\mathrm{~g})$.

2. Administrative record available and Secretary intends to defend. If the administrative record is available, the court should decide the case in accordance with the substantial evidence standard of section $405(\mathrm{~g}){ }^{98}$ Although a brief or other legal memoranda might be helpful to the court, especially in deciphering the complex medical testimony in disability cases, ${ }^{97}$ they are not essential under the statute. If the Secretary moves to file an answer or a brief "out of time," resolving the request. First, it should decide whether there is "good reason" for the delay.98 If not, the court should deny the motion and then decide whether there is substantial evidence in the record supporting the Secretary. ${ }^{100}$ The broader response of the First Circuit in Alameda-permitting "relaxed review" of the record where

פs See, e.g., Morrison v. Finch, 307 F. Supp. 219, 220 (D. Md. 1970).

- See, e.g., Williams v. Califano, 593 F.2d 282, 283-84 (7th Cir. 1979); Villines v. Harris, 487 F. Supp. 1278, 1280-81 (D.N.J. 1980); Bostic v. Harris, 484 F. Supp. 686 (S.D.W. Va. 1979).

${ }^{95} 42$ U.S.C. $\& 405(\mathrm{~g})$ (Supp. IV 1980) provides that the "court shall, on motion of the Secretary made before he files his answer, remand the case to the Secretary for further action by the Secretary." Such an order by the court might not be published if it is only for a computation of benefits, because the Secretary in effect would be conceding the case. $C f$. Morrison v. Finch, 307 F. Supp. 219, 220 (D. Md. 1970) (remand to allow Secretary to obtain additional evidence).

${ }^{86}$ See, e.g., Williams v. Califano, 593 F.2d 282, 284-85 (7th Cir. 1979); Estes v. Harris, 512 F. Supp. 1106, 1110 (S.D. Ohio 1981); Johnson v. Harris, 512 F. Supp. 339, 343 (S.D. Ohio 1981); Bostic v. Harris, 484 F. Supp. 686, 687 (S.D.W. Va. 1979).

97 Alameda v. Secretary of HEW, 622 F.2d 1044, 1046 (1st Cir. 1980). The court in Alameda found a brief often "essential in complicated medical and technical social security cases," id. at 1046, but concluded that the reviewing court may rely on the plaintiff's brief where none has been submitted by the Secretary, describing the problem as the "predicament of flying on one wing," id. at 1049.

${ }^{\circ 8}$ Bostic v. Harris, 484 F. Supp. 686, 687 (S.D.W. Va. 1979).

92 Id. at 688 .

${ }^{100} I d$. at 688-89 (motion to file answer out of time denied because there was no good reason for delay; default judgment granted after review of the record for evidence supporting the Secretary). See Howard v. Weinberger, 489 F.2d 217, 217 (5th Cir. 1974) (granting motion to file answer out of time when transcript also to be filed late). 
the Secretary filed an answer and transcript but was late in filing the required memorandum in support of his position ${ }^{101}$-is inappropriate. The interests cited by the court ${ }^{102}$ might be persuasive to a legislature, but a court's standard of review is governed by section 405(g). Moreover, the court's analogy to the rule 37 discovery sanction cases ${ }^{103}$ is inapposite. When the plaintiff sues the government in an ordinary civil case, his preparations can be hampered if the government refuses to obey discovery orders. In the Social Security context, however, the claimant may in fact benefit from the Secretary's failure to file a brief because such a brief would direct the court's attention to evidence in the record supporting his decision. Although the reviewing court must examine the record for substantial evidence, without the Secretary's brief it may be more influenced by the claimant's emphasis on the lack of substantial evidence in the record. Applying a standard of "relaxed review" is thus not only contrary to the statute, but unnecessary from the claimant's perspective.

3. Administrative record unavailable but Secretary intends to defend. Where the Secretary indicates an intention to defend by filing for an extension of time or contesting the claimant's motion for a default judgment, but is in default in filing a transcript of the administrative record, the court is faced with a dilemma. It can penalize the government by permitting the claimant to establish his claim, thus bypassing the command of section $405(\mathrm{~g})$, or it can grant the Secretary extensions of time, thus abiding by section 405(g) but indefinitely prolonging a final decision. This comment has demonstrated that the latter approach is required by the Social Security Act as it currently stands.

The court might be able to compel production by issuing a writ of mandamus to the Secretary, subject to fine and contempt sanctions. ${ }^{104}$ Although the Supreme Court has interpreted section 405(h) to preclude review by the district courts under federal question jurisdiction, ${ }^{105}$ the question of mandamus jurisdiction ${ }^{108}$ re-

${ }^{101}$ Alameda v. Secretary of HEW, 622 F.2d 1044, 1048-49 (1st Cir. 1980).

102 Id. at 1047. See supra note 60.

${ }^{103} 622$ F.2d at 1048 n.4.

104 The main requirements for mandamus are "the existence of a clear right in the plaintiff to demand the performance by the defendant of a plainly defined, peremptory, and ministerial duty, and the lack of an adequate remedy other than mandamus." Vishnevsky v. United States, 581 F.2d 1249, 1253 (7th Cir. 1978). See also Marbury v. Madison, 5 U.S. (1 Cranch) 137, 168-69 (1803); Schulke v. United States, 544 F.2d 453, 455 (10th Cir. 1976).

${ }^{105}$ Weinberger v. Salf, 422 U.S. 749, 756-57 (1975). See supra note 26.

10628 U.S.C. $\$ 1361$ (1976) ("The district courts shall have original jurisdiction of any action in the nature of mandamus to compel an officer or employee of the United States or 
mains open. ${ }^{107}$ Another appropriate basis for a mandamus order is the All Writs Act. ${ }^{108}$ The court could take jurisdiction under section $405(\mathrm{~g})^{109}$ and, in accordance with the All Writs Act, issue a writ "necessary or appropriate"110 in aid of its jurisdiction. Use of mandamus is consistent with section 405(g)'s standard of review, but allows the court to compel the Secretary to file a certified copy of the transcript, without which the court cannot proceed.

Mandamus may be a realistic solution to part of the problem, but in practice it has significant limitations. The Secretary will tend to focus his resources on those cases in which the writ is issued, ${ }^{111}$ resulting in an inequitable and unplanned allocation of re-

any agency thereof to perform a duty owed to the plaintiff.").

${ }^{107}$ See Mathews v. Eldridge, 424 U.S. 319 (1976). The Court held that jurisdiction was proper under section $405(\mathrm{~g})$, and therefore did not consider the plaintiff's contention that mandamus jurisdiction was also proper. Id. at $332 \mathrm{n} .12$. Several lower courts have relied on mandamus jurisdiction in the Social Security context. See, e.g., Elliott v. Weinberger, 564 F.2d 1219, 1227 \& nn. 11-12 (9th Cir. 1977) (upholding jurisdiction under section 1361 to review denial of hearing before recoupment), modified sub nom. Califano v. Yamasaki, 442 U.S. 682 (1979) (finding jurisdiction under section 405 (g) without discussing section 1361); DeLao v. Califano, 560 F.2d 1384, 1388 (9th Cir. 1977) (section 1361 provides alternate basis for jurisdiction in class action challenging termination of benefits without prior hearing); White v. Mathews, 559 F.2d 852, 856 (2d Cir. 1977) (section 1361 jurisdiction to issue order compelling reduction in unreasonable administrative delays), cert. denied sub nom. Califano v. White, 435 U.S. 908 (1978); Cockrum v. Califano, 475 F. Supp. 1222, 1230-31 (D.D.C. 1979) (dictum) (court can take jurisdiction under section 1361 in class action for delay in administrative hearings); Lyons v. Weinberger, 376 F. Supp. 248, 255 (S.D.N.Y. 1974) (section 1361 is one basis for jurisdiction over class action challenging termination of benefits without notice and hearing). Cf. Alameda v. Secretary of HEW, 622 F.2d 1044, 1049 n.5 (1st Cir. 1980) (mandamus question not decided); Poe v. Mathews, 572 F.2d 137, 138 (6th Cir. 1978) (per curiam) (same); Villines v. Harris, 487 F. Supp. 1278, 1282 (D.N.J. 1980) (same). ${ }^{208} 28$ U.S.C. $\$ 1651$ (1976) provides:

(a) The Supreme Court and all courts established by Act of Congress may issue all writs necessary or appropriate in aid of their respective jurisdictions and agreeable to the usages and principles of law.

(b) An alternative writ or rule nisi may be issued by a justice or judge of a court which has jurisdiction.

${ }^{100}$ The All Writs Act does not independently provide jurisdiction. See United States v. New York Tel. Co., 434 U.S. 159, 172 (1977) ("This Court has repeatedly recognized the power of a federal court to issue such commands under the All Writs Act as may be necessary or appropriate to effectuate and prevent the frustration of orders it has previously issued in its exercise of jurisdiction otherwise obtained . . . ."); ITT Community Dev. Corp. v. Barton, 569 F.2d 1351, 1358 (5th Cir. 1978) ("The authority of a district court to invoke the extraordinary powers conferred by the All Writs Act . . . assumes . . . the presence of an independent source of subject matter jurisdiction . . . .").

12028 U.S.C. \& 1651 (1976). The All Writs Act may be applied "flexibly" and in a way calculated to achieve the "ends of justice." United States v. New York Tel. Co., 434 U.S. 159, 173 (1977) (quoting Adams v. United States ex rel. McCann, 317 U.S. 269, 273 (1942)).

111 For a discussion of these concerns in the context of private rights of initiation, see Stewart \& Sunstein, Public Programs and Private Rights, 95 Harv. L. Rev. 1193, 1267-71 (1982). 
sources. Moreover, mandamus traditionally has been granted only when there is a "clear right' in the plaintiff to the relief sought and a 'clear duty' on the part of the defendant to do the act in question."112 Although the Secretary's duty to file a certified copy of the transcript with his answer within the time provided by the federal rules is clearly defined, in some cases it will be impossible to comply: the record may be lost, inaudible, or otherwise impossible to transcribe. ${ }^{113}$ In such cases, the court must accept the delay and remand for another administrative hearing. ${ }^{114}$

\section{A Proposed Legislative Response}

Where the Secretary indicates an intent to defend but is in default in submitting the administrative record, serious inequities result; many deserving claimants experience lengthy delays before receiving the benefits due them under the Act. ${ }^{118}$ Congressional action is needed to increase claims-administration appropriations and to balance more equitably the consideration courts must give to the Secretary's administrative problems and to claimants' rights to prompt resolution of their eligibility status.

Congress should authorize the claimants to challenge the Secretary's delay. Where the Secretary fails to file the transcript of the administrative record within the time allowed for filing the answer, he should be required to show a good faith effort to produce the record. If his delay is not in good faith, the court should be authorized to institute interim payment of benefits to the claimant.

The definition of "good faith" would depend on Congress's balancing of the policies favoring each of the two parties. ${ }^{116} \mathrm{~A}$

112 Lyons v. Weinberger, 376 F. Supp. 248, 255 (S.D.N.Y. 1974) (quoting Burnett v. Tolson, 474 F.2d 877 (4th Cir. 1973)).

113 See, e.g., Steward v. Harris, 509 F. Supp. 31, 33 (N.D. Cal. 1980) (remand because record inadequate and "liberally sprinkled with 'inaudibles' when plaintiff is speaking"); Smith v. Califano, 470 F. Supp. 898, 899 (D.D.C. 1978) (remand because portion of the administrative record had been lost).

214 The Social Security Disability Amendments of 1980, Pub. L. No. 96-265, § 307, 94 Stat. 441,458 , amended section $405(\mathrm{~g})$ to allow the Secretary to remand a case for good cause before an answer is filed. "Good cause," according to the Conference Report, would include a lost or inaudible record, or other record that could not be transcribed. The conferees stated, however, "that remands on the basis of these breakdowns in the administrative process should be kept to a minimum so that persons appealing their decision are not unduly burdened by the resulting delay." H.R. REP. No. 944, 96th Cong., 2d Sess. 59 (1980).

115 See supra notes 33-40 and accompanying text.

110 Congress could adopt a good faith standard that would be left undefined in the statute. See, e.g., 11 U.S.C. $\$ 1129$ (a)(3) (Supp. IV 1980) (Bankruptcy Code permits courts to confirm a reorganization plan if plan was proposed in "good faith and not by any means 
broad definition of good faith, for example, would consider the Secretary's lack of resources; ${ }^{112}$ it might also excuse failure to produce the transcript if the record is lost or inaudible. ${ }^{118} \mathrm{~A}$ narrow definition of good faith, on the other hand, would preclude the lack-of-resources defense; it would indicate a greater willingness to make payments to potentially ineligible claimants in exchange for speedier payments in general.

Under present law, payments to a claimant ultimately found to be ineligible are "overpayments"; 119 recoupment of overpayments is prohibited where a recipient is not at fault and where it would defeat the purposes of the Social Security Act or "would be against equity or good conscience."120 The desirability of extending this rule to the interim payments ordered by a court when the Secretary has in bad faith delayed filing the record depends on how the good faith standard is defined. If good faith is narrowly defined, a greater number of possibly ineligible claimants would receive interim benefits, and the recoupment standard should be relaxed to allow the largest recovery possible from claimants ultimately found ineligible. ${ }^{21}$

forbidden by law"); 15 U.S.C. $\$ 1221$ (e) (1976) (defining "good faith" in context of automobile dealer suits against manufacturers as "duty . . . to act in a fair and equitable manner"). See also the cases considering delays in granting hearings under section 205(b) of the Social Security Act, 42 U.S.C. § 405(b) (1976): Caswell v. Califano, 583 F.2d 9 (1st Cir. 1978); White v. Mathews, 559 F.2d 852 (2d Cir. 1977), cert. denied sub nom. Califano v. White, 435 U.S. 908 (1978); Cockrum v. Califano, 475 F. Supp. 1222 (D.D.C. 1979). These courts held that the statutory command to provide a claimant with a "reasonable . . . opportunity for a hearing," 42 U.S.C. $\$ 405(\mathrm{~b})$, was violated when the delay exceeded a specific amount of time. Contra Wright v. Califano, 587 F.2d 345 (7th Cir. 1979).

${ }^{217}$ For cases on delay in holding administrative hearings, compare Wright v. Califano, 587 F.2d 345, 353 (7th Cir. 1979) ("legislatively imposed 'reasonable dispatch' duty must be judged in the light of the resources that Congress has supplied to the agency for the exercise of its functions") with Caswell v. Califano, 583 F.2d 9, 17 (1st Cir. 1978) (inadequate resources do not bar vindication of legal rights); White v. Mathews, 559 F.2d 852, 859 (2d Cir. 1977) (rejecting Secretary's claim that delays were reasonable because of inadequate resources), cert. denied sub nom. Califano v. White, 435 U.S. 908 (1978); and Cockrum v. Califano, 475 F. Supp. 1222, 1239 (D.D.C. 1979) (inadequacy of funding goes "to the form of relief, not to the issue of entitlement to relief').

118 See supra note 113.

118 See 42 U.S.C. $\S 404$ (1976); 20 C.F.R. $\$ 404.501$ (1981).

12042 U.S.C. $\$ 404$ (b) (1976) ("In any case in which more than the correct amount of payment has been made, there shall be no . . . recovery by the United States from[] any person who is without fault if such . . . recovery would defeat the purpose of this subchapter or would be against equity and good.conscience.").

121 But see Goldberg v. Kelly, 397 U.S. 254, 278-79 (1970) (Black, J., dissenting) (noting that recoupment from ineligible recipients is highly improbable given the "judgment-proof" nature of welfare claimants). 


\section{Conclusion}

This comment has argued that section 405 (g) defines the exclusive standard of review for denial of Social Security benefits: review of the record for substantial evidence supporting the Secretary. A relaxed standard of review under rule 55(e) or by analogy to rule 37 in situations of default violates the exclusivity mandated by the Social Security Act.

The frequent inequity of this standard cannot be denied. Although a mandamus proceeding is consistent with the statutory framework and offers an opportunity for occasional relief, legislative action is needed to balance more equitably a claimant's need for a speedy appeal and the government's interest in avoiding payments to ineligible claimants. Interim payment of benefits to claimants when the Secretary in bad faith delays filing the administrative record, coupled with a relaxed standard for recoupment of benefits to individuals eventually found to be ineligible, offers a workable solution in at least the most egregious cases. 